\title{
Factors Affecting Entrepreneurial Intention among UniSZA Students
}

\author{
Zaharah Ghazali $^{1}$, Nor Asmahani Ibrahim ${ }^{1} \&$ Fakhrul Anwar Zainol ${ }^{1}$ \\ ${ }^{1}$ Faculty of Business Management \& Accountancy, Universiti Sultan Zainal Abidin, Terengganu, Malaysia \\ Correspondence: Zaharah Ghazali, Faculty of Business Management \& Accountancy, Universiti Sultan Zainal \\ Abidin, Terengganu, 21300, Malaysia. Tel: 60-13-901-4907. E-mail: zaharahg@unisza.edu.my
}

\author{
Received: April 18, 2012 Accepted: September 14, 2012 Online Published: December 31, 2012 \\ doi:10.5539/ass.v9n1p85 URL: http://dx.doi.org/10.5539/ass.v9n1p85
}

\begin{abstract}
Graduates contributions to entrepreneurship would stimulate the country's economic growth. The aim of this study is to determine and investigate factors influence on students' perception of the entrepreneurial intention, in order to present the most contemporary future generation of entrepreneurs that can shape the future of the economy and the country. The area of this study covers demographic profiles, attitudinal and behavioral factors, and how these influence the intentions of students to become entrepreneurs. The finding suggests that the female students had significantly higher attitude and social skill and desire to succeed as compared to the male students. There was no significant difference with regards to race, age, parental working background, family and relative engaged in business, and heard about entrepreneurship ensuring that entrepreneurs are not clustered in any of these variables. Another major finding indicates that those who attended entrepreneurship course/training had significantly higher attitude and social skill. Most importantly, marketing skill, desire to success, leadership skill, and innovation and creativity inspire graduates in choosing entrepreneurship. Thus, examining the selected key unemployment of graduates' issues from an entrepreneurship perspective can help to establish harmony and meaningful cooperation between entrepreneurs and learning institutions.
\end{abstract}

Keywords: entrepreneurial intention, attitude, demographic profiles, graduate

\section{Introduction}

\subsection{Background of the Study}

The unemployment of graduates has become a national issue in Malaysia as the number of graduates from public and private higher educational institutions that join the job market increases each year. Unfortunately, this proliferation not only exceeds the current demand for their services but also the skills of new graduates do not match those needed by employers. Hence, academic qualifications can no longer guarantee immediate employment upon graduation, and instead, graduates are required to show a positive attitude towards the changing job market (Morshidi et al., 2004).

It has been proposed that graduates widen their career scope by investigating entrepreneurship as a possible basis for a career. In fact, entrepreneurship would help these new graduates develop their own career and also ease the current unemployment issue by expanding the job market (Norasmah, 2004). Entrepreneurship has been acknowledged by most entrepreneurial researchers as a solution to the problem of unemployed graduates (Kamariah et al., 2004; Salmah, 2006).

While development in entrepreneurship has had notable effects on the business world today, a paradigm shift among graduates is needed, as their contributions to entrepreneurship would stimulate the country's economic growth, and help it move towards becoming a developed nation by 2020 .

Universities and colleges have taken many steps to strengthen its education sector. Entrepreneurial education is primarily the focus of Centre of Entrepreneurship, Universiti Sultan Zainal Abidin (UniSZA). Students from various academic programs are required to take courses in foundations of entrepreneurial knowledge, skills and attitudes. However, it is unknown whether contextual founding conditions or rather personality traits that drove students' intention to self-employment. In order to design an effective program, policy makers have to know the factors mentioned above that need to be emphasized (Autio et al., 1997). Thus, there is a need to conduct a study focusing on students' perception of the entrepreneurial intention and the factors affecting their decisions.

The aim of this study is to determine and investigate factors influence on students' perception of the 
entrepreneurial intention, in order to present the most contemporary future generation of entrepreneurs that can shape the future of the economy and the country. The research question has been defined according to the research aim as "What is the UniSZA students' perception towards entrepreneurship based on demographic profiles and attitudinal and behavioral factors?"

\subsection{Background of UniSZA}

Universiti Sultan Zainal Abidin formerly known as Universiti Darul Iman Malaysia (UDM) is the eighteenth public university in Malaysia. Established in 2006, the University has three campuses in Kota, Gong Badak and Besut. The University has 9 faculties which offer programs in diploma, bachelor's degree, master's degree and doctor of philosophy. Programs offered at the University include languages and communication, informatics, Islamic contemporary studies, business management and accountancy, agriculture and biotechnology, medicine and health science, innovative design and technology, law and international relations and food technology.

There are over 50 student societies in a variety of fields where students develop skills in leadership, management, organization and entrepreneurial spirit among others. UniSZA hopes to produce leaders in various fields through knowledge, openness, responsibility and an appreciation of diversity to benefit all. Apart from that, the University also aims to shape talented leaders who are both knowledgeable and cultured, with an international outlook.

\section{Literature Review}

Entrepreneurship education tries to develop in the participants the intention to perform entrepreneurial behaviors, entrepreneurial knowledge and desirability of the entrepreneurial activity (Liñán, 2004). There are various entrepreneurial education scope and structure among higher education in Malaysia.

College students are trained as preparation to enter the business world according to their areas of study. However, whether they would be officers or entrepreneurs after graduation would be determined by their intent. An intention is an anticipated outcome guided by planned actions. The theory of planned behavior is linked between attitudes and behaviors (Ajzen, 1991). Intentions predict deliberate behaviors because behavior can be planned. Intention is assumed to take hold of emotional factors that influence behavior and indicate one's effort to try to perform intentional behavior. In the context of entrepreneurship, intension is identified as the important property for establishing an organization (Kantz \& Gartner, 1988) and as a predictor of new reliable enterprise (Krueger, Michael \&Casrud, 2000).

Entrepreneurial intention of university students in various cultural contexts indicated that the encouragement from university environment affects the entrepreneurial confidence of university students (Autio et al., 1997). Educational support through professional education in universities is an efficient way of obtaining necessary knowledge about entrepreneurship. This is supported by the study done by Wang and Wong (2004) who pointed out that entrepreneurial dreams of many students are hindered by inadequate preparation of the academic institution. The school and education system also play a critical role in identifying and shaping entrepreneurial traits (Ibrahim \&Soufani, 2002). Other studies have pointed out that entrepreneurship education, especially education that provides technological training, is crucial to enhance entrepreneurs' innovation skills in an increasingly challenging environment (Galloway \& Brown, 2002; Garavan \& O’Cinneide, 1994).
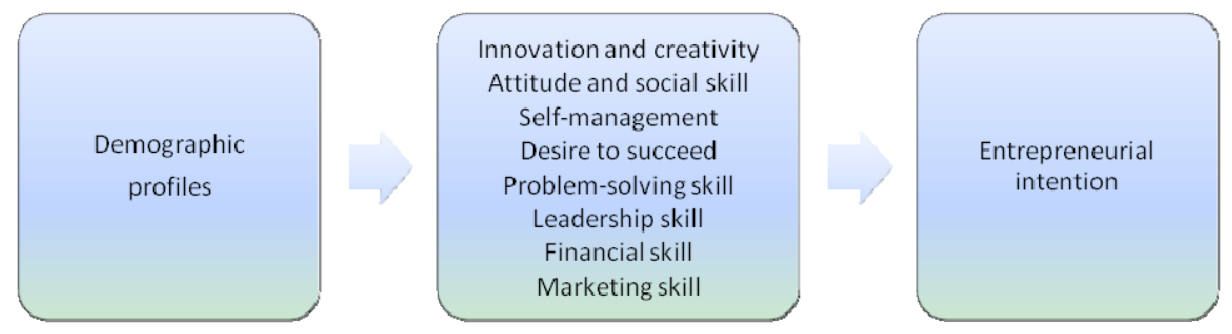

Figure 1. Conceptual Framework

Figure 1 shows the conceptual framework for this study is built based on the Theory of Planned Behaviour by Ajzen (1991). On the basis of previous studies explained above, the area of this study covers demographic profiles, attitudinal and behavioral factors, and how these influence the intentions of students to become entrepreneurs.

\section{Methodology}

This study was carried out through a survey method, using questionnaires as the main instrument to collect data. The population for this study consisted of all students at the undergraduate level registered during the academic 
year 2010-2011 at UniSZA. The sampling method employed for this study was an intercept survey sampling whereby the students were intercepted at the entrepreneurship program. This method of sampling and analysis is adopted from Ramayah and Harun (2005). They further defined that it was the only viable sampling technique given that it was impossible to occupy all the students enrolled. However, a limitation was identified due to sampling methodological choice. It is related to the fact that only selecting all the available students attended entrepreneurship program. Accordingly, it did not capture responses from all the different schools of program in the university.

The questionnaire consisted of 2 parts; the first part had 85 questions eliciting information about innovation and creativity (11), attitude and social skill (10), self-management (12), desire to succeed (11), problem-solving skill (8), leadership skill (7), financial skill (4), marketing skill (8), and also entrepreneurial intention (14). The second part consisted of questions on demographic profile of the respondents. The respondents were asked to state their agreement/disagreement on statements on a 5 -point Likert scale with $(1=$ strongly disagree, $5=$ strongly agree).

This study will look at reliability of the data obtained from the survey. Cronbach's Alpha is most widely used to measure the internal consistency of a scale. As such, by running the survey data on the SPSS software for each of the variables the following results were obtained.

Table 1. Reliability coefficients for the variables

\begin{tabular}{lccc}
\hline Variable & Number of item & Item dropped & Cronbach's Alpha \\
\hline Innovation and creativity & 11 & - & 0.80 \\
Attitude and social skill & 10 & - & 0.86 \\
Self-management & 12 & - & 0.87 \\
Desire to succeed & 11 & - & 0.88 \\
Problem-solving skill & 8 & - & 0.85 \\
Leadership skill & 7 & - & 0.84 \\
Financial skill & 4 & - & 0.82 \\
Marketing skill & 8 & - & 0.75 \\
Entrepreneurial intention & 14 & - & 0.88 \\
\hline
\end{tabular}

Table 1 shows the Cronbach's Alpha coefficient that was computed for each of the variables in the study to ensure goodness of measure. All the coefficients indicated values exceeding 0.75 which further strengthens the reliability of the instruments used for this study.

\section{Results}

\subsection{Descriptive Statistics}

In this section, the data analysis is presented. There were 250 questionnaires collected, but 43 questionnaires were incomplete or invalid. A total of 207 valid questionnaires were coded for statistical analysis using the SPSS 14.0 to analyze profile of the respondents, descriptive statistics of the variables, and inter-correlations of the variables.

Table 2. Profile of the respondents

\begin{tabular}{llcc}
\hline Variable & Item & Frequency & Percentage \\
\hline Gender & Male / Female & $46 / 161$ & $22.2 / 77.8$ \\
Ethnicity & Malay / Chinese / Indian / Others & $197 / 2 / 3 / 5$ & $95.2 / 1.0 / 1.4 / 2.4$ \\
Age & $15-19 / 20-24 / 25-29$ & $87 / 118 / 2$ & $42.0 / 57.0 / 1.0$ \\
Parental working background & Government servant & 62 & 30.0 \\
& Private company & 39 & 18.8 \\
& Self-employed/businessperson & 90 & 43.5 \\
& Others & 16 & 7.7 \\
Family with business & Yes / No & $129 / 78$ & $62.3 / 37.7$ \\
Relative with business & Yes / No & $180 / 27$ & $87.0 / 13.0$ \\
Heard about entrepreneurship & Yes / No & $204 / 3$ & $98.6 / 1.4$ \\
Attended course/training & Yes / No & $173 / 34$ & $83.6 / 16.4$ \\
\hline
\end{tabular}


The profile of the respondents is presented in Table 2. Almost three quarters of the respondents were female and most of their ages range from 20 to 24 years. The results for ethnicity indicate that Malay was the majority (95\%) respondents with the rest were Chinese, Indian and others. Near half of the respondents have self-employed/businessperson working parents, and in average, three quarters of them have family and relative involved in business. This study also requested information about whether the respondents had attended any course or training on entrepreneurship and more than $80 \%$ indicated they have attended some form of a course or training.

Table 3. Descriptive statistics of the variables

\begin{tabular}{lcc}
\hline Variable & Mean & Standard deviation \\
\hline Innovation and creativity (IAC) & 3.89 & .491 \\
Attitude and social skill (AASS) & 4.33 & .484 \\
Self-management (SM) & 4.12 & .447 \\
Desire to succeed (DTS) & 4.53 & .434 \\
Problem-solving skill (PSS) & 4.14 & .482 \\
Leadership skill (LS) & 3.83 & .592 \\
Financial skill (FS) & 3.62 & .861 \\
Marketing skill (MS) & 4.16 & .458 \\
Entrepreneurial intention (EI) & 4.27 & .490 \\
\hline
\end{tabular}

Table 3 shows the mean and standard deviations for each of the nine factors. A low standard deviation indicates that the data points tend to be very close to the mean, whereas high standard deviation indicates that the data points are spread out over a large range of values.

Table 4. Inter-correlations of the variables

\begin{tabular}{llllllllll}
\hline Item & IAC & AASS & SM & DTS & PSS & LS & FS & MS & EI \\
\hline IAC & 1 & & & & & & & & \\
AASS & $.409^{* *}$ & 1 & & & & & & \\
SM & $.579^{* *}$ & $.520^{* *}$ & 1 & & & & & \\
DTS & $.397^{* *}$ & $.423^{* *}$ & $.589^{* *}$ & 1 & & & & \\
PSS & $.496^{* *}$ & $.439^{* *}$ & $.686^{* *}$ & $.490^{* *}$ & 1 & & & \\
LS & $.492^{* *}$ & $.412^{* *}$ & $.528^{* *}$ & $.469^{* *}$ & $.558^{* *}$ & 1 & & \\
FS & $.254^{* *}$ & .118 & $.362^{* *}$ & .098 & $.349^{* *}$ & $.204^{* *}$ & 1 & & \\
MS & $.536^{* *}$ & $.536^{* *}$ & $.611^{* *}$ & $.537^{* *}$ & $.564^{* *}$ & $.611^{* *}$ & $.270^{* *}$ & 1 & \\
EI & $.496^{* *}$ & $.448^{* *}$ & $.555^{* *}$ & $.610^{* *}$ & $.517^{* *}$ & $.568^{* *}$ & $.163^{*}$ & $.618^{* *}$ & 1 \\
\hline
\end{tabular}

$* * \mathrm{p}<0.01, * \mathrm{p}<0.05$

Table 4 shows the result of the inter-correlations of the variables computed by Pearson correlation coefficient. From the inter-correlations of the main variables it is seen that all the 8 determinants of entrepreneurial intention are positively related such as the higher the values of the determinants the higher the entrepreneurial intention.

\subsection{T-test and ANOVA}

Several tests were conducted by applying $t$-test and one-way ANOVA to examine if there is any difference in the variables of the study. Tables 5 to 10 show the results of the analyses. 
Table 5. Differences in the variables by gender

\begin{tabular}{lccc}
\hline Variable & \multicolumn{2}{c}{ Mean } & \multirow{2}{*}{-value } \\
\cline { 2 - 3 } & Male & Female & 1.02 \\
\hline Innovation and creativity & 3.96 & 3.87 & $-2.03^{*}$ \\
Attitude and social skill & 4.18 & 4.37 & -1.11 \\
Self-management & 4.05 & 4.14 & $-2.32^{*}$ \\
Desire to succeed & 4.39 & 4.58 & -0.86 \\
Problem-solving skill & 4.08 & 4.15 & 1.21 \\
Leadership skill & 3.92 & 3.80 & 0.23 \\
Financial skill & 3.65 & 3.61 & -1.45 \\
Marketing skill & 4.07 & 4.18 & -0.58 \\
Entrepreneurial intention & 4.23 & 4.28 & \\
\hline
\end{tabular}

$* \mathrm{p}>0.05$

Table 5 shows that female students were found to be significantly higher attitude and social skill and desire to succeed as compared to the male students.

A one-way between subjects ANOVA was conducted to compare the effect of ethnic group, age group and parental working background as independent variables on all terms of dependent variables in this study. In Table 6 and 7, they show outputs for these tests where there are no statistically significant differences.

Table 6. Mean factor scores by ethnic group and age group

\begin{tabular}{|c|c|c|c|c|c|c|c|}
\hline \multirow[t]{2}{*}{ Variable } & \multicolumn{4}{|c|}{ Ethnicity } & \multicolumn{3}{|c|}{ Age } \\
\hline & Malay & Chinese & Indian & Others & $15-19$ & $20-24$ & 25.29 \\
\hline Innovation and creativity & 3.88 & 3.91 & 4.58 & 3.96 & 3.83 & 3.93 & 4.50 \\
\hline Attitude and social skill & 4.32 & 4.20 & 4.37 & 4.56 & 4.33 & 4.32 & 4.45 \\
\hline Self-management & 4.11 & 4.25 & 4.22 & 4.35 & 4.08 & 4.15 & 4.29 \\
\hline Desire to succeed & 4.52 & 4.59 & 4.64 & 4.91 & 4.61 & 4.48 & 4.50 \\
\hline Problem-solving skill & 4.14 & 3.56 & 4.08 & 4.35 & 4.17 & 4.11 & 4.50 \\
\hline Leadership skill & 3.81 & 3.71 & 4.19 & 4.37 & 3.76 & 3.86 & 4.50 \\
\hline Financial skill & 3.60 & 4.00 & 4.00 & 3.95 & 3.54 & 3.66 & 4.75 \\
\hline Marketing skill & 4.14 & 3.94 & 4.58 & 4.53 & 4.17 & 4.14 & 4.63 \\
\hline Entrepreneurial intention & 4.26 & 3.89 & 4.60 & 4.56 & 4.30 & 4.24 & 4.50 \\
\hline
\end{tabular}

Table 6 shows mean scores of the one way ANOVA test indicated that there were no significant differences among the students of the various ethnic and age groups in all terms.

Table 7. Mean factor scores by parental working background

\begin{tabular}{lcccc}
\hline Variable & \multicolumn{3}{c}{ Mean } \\
\cline { 2 - 4 } & $\begin{array}{c}\text { Government } \\
\text { servant }\end{array}$ & $\begin{array}{c}\text { Private } \\
\text { company }\end{array}$ & $\begin{array}{c}\text { Self-employed/ } \\
\text { businessperson }\end{array}$ & Others \\
\hline Innovation and creativity & 3.80 & 4.03 & 3.90 & 3.89 \\
Attitude and social skill & 4.27 & 4.46 & 4.33 & 4.23 \\
Self-management & 4.03 & 4.15 & 4.17 & 4.10 \\
Desire to succeed & 4.45 & 4.61 & 4.56 & 4.56 \\
Problem-solving skill & 4.03 & 4.20 & 4.18 & 4.18 \\
Leadership skill & 3.73 & 3.86 & 3.88 & 3.81 \\
Financial skill & 3.42 & 3.67 & 3.68 & 3.97 \\
Marketing skill & 4.07 & 4.21 & 4.20 & 4.08 \\
Entrepreneurial intention & 4.20 & 4.37 & 4.28 & 4.21 \\
\hline
\end{tabular}


Table 7 shows mean scores of the one way ANOVA test indicated that there were no significant differences among the students of the various parental working backgrounds in all terms.

Table 8 . Mean and $t$-value factor scores by family and relative engaged in business

\begin{tabular}{|c|c|c|c|c|c|c|}
\hline \multirow{3}{*}{ Variable } & \multicolumn{3}{|c|}{ Family engaged in business } & \multicolumn{3}{|c|}{ Relative engaged in business } \\
\hline & \multicolumn{2}{|c|}{ Mean } & \multirow{2}{*}{$t$-value } & \multicolumn{2}{|c|}{ Mean } & \multirow{2}{*}{$t$-value } \\
\hline & Yes & No & & Yes & No & \\
\hline Innovation and creativity & 3.90 & 3.89 & -0.07 & 3.90 & 3.82 & 0.85 \\
\hline Attitude and social skill & 4.31 & 4.35 & -0.51 & 4.33 & 4.28 & 0.52 \\
\hline Self-management & 4.13 & 4.09 & 0.65 & 4.12 & 4.09 & 0.36 \\
\hline Desire to succeed & 4.52 & 4.56 & -0.57 & 4.52 & 4.60 & -0.87 \\
\hline Problem-solving skill & 4.16 & 4.10 & 0.94 & 4.16 & 4.00 & 1.61 \\
\hline Leadership skill & 3.87 & 3.76 & 1.32 & 3.86 & 3.63 & 1.86 \\
\hline Financial skill & 3.61 & 3.63 & -0.14 & 3.64 & 3.49 & 0.84 \\
\hline Marketing skill & 4.18 & 4.12 & 0.94 & 4.17 & 4.08 & 0.90 \\
\hline Entrepreneurial intention & 4.28 & 4.24 & 0.54 & 4.29 & 4.15 & 1.40 \\
\hline
\end{tabular}

Table 8 shows the result of the $t$-test indicated that there were no significant differences among the students between groups, those who said their family/relative had engaged in business and those who had no family/relative engaged in business. Hence, family and relative involvement in business do not appear to contribute to the scale of the variables.

Table 9. Differences in the variables by heard about entrepreneurship and attended course/training

\begin{tabular}{|c|c|c|c|c|c|c|}
\hline \multirow{3}{*}{ Variable } & \multicolumn{3}{|c|}{ Heard about entrepreneurship } & \multicolumn{3}{|c|}{ Attended course/training } \\
\hline & \multicolumn{2}{|c|}{ Mean } & \multirow{2}{*}{$t$-value } & \multicolumn{2}{|c|}{ Mean } & \multirow{2}{*}{$t$-value } \\
\hline & Yes & No & & Yes & No & \\
\hline Innovation and creativity & 3.90 & 3.73 & 0.59 & 3.90 & 3.86 & 0.49 \\
\hline Attitude and social skill & 4.32 & 4.57 & -0.86 & 4.36 & 4.14 & $2.51^{*}$ \\
\hline Self-management & 4.12 & 4.36 & -0.95 & 4.13 & 4.08 & 0.54 \\
\hline Desire to succeed & 4.53 & 4.91 & -1.51 & 4.55 & 4.47 & 0.91 \\
\hline Problem-solving skill & 4.14 & 4.21 & -0.25 & 4.16 & 4.04 & 1.30 \\
\hline Leadership skill & 3.83 & 3.76 & 0.19 & 3.84 & 3.75 & 0.84 \\
\hline Financial skill & 3.64 & 2.33 & 2.65 & 3.64 & 3.54 & 0.62 \\
\hline Marketing skill & 4.16 & 4.21 & -0.20 & 4.16 & 4.13 & 0.45 \\
\hline Entrepreneurial intention & 4.27 & 4.36 & -0.32 & 4.30 & 4.13 & 1.86 \\
\hline
\end{tabular}

$* \mathrm{p}>0.05$

Table 9 shows the result of the mean differences between variables employed by $t$-test. No significant difference was found for the heard about entrepreneurship, however, those who had attended courses/training on entrepreneurship indicated significantly higher attitude and social skill. 


\subsection{Relationship between Best Predictors and the Dependent Variable}

Table 10. Variant analysis

\begin{tabular}{lllllll}
\hline Model & Sum of Squares & $\mathrm{df}$ & Mean Square & F & Sig. \\
\hline $1 \quad$ Regression & 18.830 & 1 & 18.830 & 126.443 & $.000(\mathrm{a})$ \\
& Residual & 30.529 & 205 & .149 & & \\
& Total & 49.359 & 206 & & & \\
2 & Regression & 24.184 & 2 & 12.092 & 97.984 & $.000(\mathrm{~b})$ \\
& Residual & 25.175 & 204 & .123 & & \\
& Total & 49.359 & 206 & & 73.513 & $.000(\mathrm{c})$ \\
3 & Regression & 25.702 & 3 & 8.567 & & \\
& Residual & 23.658 & 203 & .117 & & \\
& Total & 49.359 & 206 & & 57.632 & $.000(\mathrm{~d})$ \\
4 & Regression & 26.307 & 4 & 6.577 & & \\
& Residual & 23.052 & 202 & .114 & & \\
& Total & 49.359 & 206 & & & \\
\hline
\end{tabular}

a Predictors: (Constant), MS

b Predictors: (Constant), MS, DTS

c Predictors: (Constant), MS, DTS, LS

d Predictors: (Constant), MS, DTS, LS, IAC

e Dependent Variable: EI

Table 10 shows the best subset of predictors for entrepreneurial intention employed by analysis of variant included the dependent variables: marketing skill, desire to success, leadership skill, and innovation and creativity. The probability of the F statistic (57.63) for the regression relationship which includes these several variables is $<0.001$, less than or equal to the level of significance of 0.05 . This study supports the research hypothesis that there is a statistically significant relationship between the best subset of independent variables and the dependent variable.

Table 11. Stepwise regression analysis

\begin{tabular}{llrrr}
\hline Model & R & \multicolumn{1}{c}{ R Square } & Adjusted R Square & \multicolumn{2}{c}{ Std. Error of the Estimate } \\
\hline 1 & $.618(\mathrm{a})$ & .381 & .378 & .38591 \\
2 & $.700(\mathrm{~b})$ & .490 & .485 & .35130 \\
3 & $.722(\mathrm{c})$ & .521 & .514 & .34138 \\
4 & $.730(\mathrm{~d})$ & .533 & .524 & .33781 \\
\hline
\end{tabular}

a Predictors: (Constant), MS

b Predictors: (Constant), MS, DTS

c Predictors: (Constant), MS, DTS, LS

d Predictors: (Constant), MS, DTS, LS, IAC

e Dependent Variable: EI

Table 11 shows the results of a stepwise regression performed on the data in which the multiple $\mathrm{R}$ for the relationship between the subset of independent variables that best predict the dependent variable is 0.73 , indicating approximately $53.3 \%$ of the variance of the entrepreneurial intention could be accounted for by marketing skill, desire to success, leadership skill, and innovation and creativity, which would be characterized as strong.

The findings showed that the female students had significantly higher attitude and social skill and desire to succeed as compared to the male students. There was no significant difference with regards to race, age, parental working background, family and relative engaged in business, and heard about entrepreneurship which further showed that entrepreneurs are not clustered in any of these variables. Another major finding was that those who attended entrepreneurship course/training had significantly higher attitude and social skill. Based on the regression analysis, 
it can be concluded that marketing skill, desire to success, leadership skill, and innovation and creativity explained as much as $53.3 \%$ of the variation in choosing entrepreneurship.

\section{Conclusion}

This research observed several significant findings through the descriptive and inferential analyses that were carried out to identify the relationship between two factors, demographic profiles and attitude towards entrepreneurship, to career choice among graduates. The demographic profiles did not have a significant effect on the entrepreneurial intention. The findings indicate that they are not sure which career path to take on, either to work for somebody drawing a fixed income or working independently but with no guarantee of fixed income.

Graduates are found to have a high attitude profile towards entrepreneurship in all the attitudinal components: innovation and creativity, attitude and social skill, self-management, desire to succeed, problem-solving skill, leadership skill, financial skill and marketing skill. Several discoveries were also made through correlation analysis. Participants' attitude towards entrepreneurship was moderately related to their behavior in choosing the field. In this context, the marketing skill component was found to have the highest moderate relationship, followed by desire to succeed. However, stepwise regression analysis showed that only four of the 8 attitudinal components were significant: marketing skill, desire to success, leadership skill, and innovation and creativity. This finding shows that it is these four factors that inspire graduates towards entrepreneurship.

Examining the selected key unemployment of graduates' issues from an entrepreneurship perspective can help to create a value-loaded global businesspeople framework for students, and establish harmony and meaningful cooperation between entrepreneurs and learning institutions. Universities are in the best position to offer the training and experiences most beneficial for students looking into an entrepreneurial career, and many enterprises in the developing world have begun at universities. This study recommends that UniSZA must have a stronger focus on the skills required by entrepreneurs in the developing world by ensuring that entrepreneurship training includes the economic and social impact of technologies; case studies of entrepreneurship; networking and mentorship by successful entrepreneurs; business education including, accounting, marketing and finance; exposure to potential investors and partners; and the history of entrepreneurial progress in the developed countries.

Most importantly, university entrepreneurial programs are designed to benefit students, faculty, and the regional business community to access to a national level entrepreneurship curriculum, resulting in improved job possibilities and greater wealth creation. Thus, in compatible with the establishment of entrepreneurial culture and the promotion of business activities can contribute to the development of socio-economic well-being of the people residing in the area and beyond.

\section{Acknowledgements}

Our sincere thanks go to all those who have contributed to making this study a success, with special thanks to our generous sponsor, the Centre of Entrepreneurship, UniSZA.

\section{References}

Ajzen, I. (1991). The theory of planned behaviour. Organizational Behaviour and Human Decision Processes, 50(2), 179-211. http://dx.doi.org/10.1016/0749-5978(91)90020-T

Autio, E., Keeley, R. H., Klofsten, M., \& Ulfstedt, T. (1997). Entrepreneurial intent among students: testing an intent model in Asia, Scandinavia and USA. Frontiers of Entrepreneurship Research. Retrieved from http://www.babson.edu/entrep/fer/papers97/autio/aut1.htm

Galloway, L., \& Brown, W. (2002). Entrepreneurship education at university: a driver in the creation of high growth firms. Education Training, 44(8-9), 398-405. http://dx.doi.org/10.1108/00400910210449231

Garavan, T. N., \& O'Cinneide, B. (1994). Entrepreneurship education and training programs: a review and evaluation - Part 1. Journal of European Industrial Training, 18(8), 3-12. http://dx.doi.org/10.1108/03090599410068024

Ibrahim, A. B., \& Soufani, K. (2002). Entrepreneurship education and training in Canada: a critical assessment. Education and Training, 44(8), 421-430. http://dx.doi.org/10.1108/00400910210449268

Kantz, J. A., \& Gartner, W. B. (1988). Properties of emerging organizations. Academy of Management Review, 13(3), 429-441.

Krueger, N. F., Michael, D. R., \& Casrud, A. L. (2000). Competing models of entrepreneurial intentions. Journal 
of Business Venturing, 15, 411-432. http://dx.doi.org/10.1016/S0883-9026(98)00033-0

Liñán, F. (2004). Intention-based models of entrepreneurship education. PiccollaImpresa/Small Business, 3, 11-35.

Othman, K., Anas, Y., \& Jusoh, W. J. W. (2004). A study of entrepreneurial intention among young Malaysian: a case study of Universiti Tenaga Nasional (UNITEN) student. Proceedings of the $3^{\text {rd }}$ International Conference on SMEs in a Global Economy: Economic Resilience in East Asia - Role of SMEs and Stakeholders held on 6-7 July 2004 at Holiday Villa Subang.

Othman, N. (2004). Bidang keusahawanan: satu alternative bagi mahasiswa. In Abdul Razaq Ahmad (Ed.), Mahasiswa abad 21 (chapter 16, pp. 201-216). Bangi: Education Faculty, Universiti Kebangsaan Malaysia.

Ramayah, T., \& Harun, Z. (2005). Entrepreneurial intention among the students of Universiti Sains Malaysia. International Journal of Management and Entrepreneurship, 1(1), 8-20.

Sirat, M., Buang, A. A., Shuib, M., Isa, A. M. M., Bakar, R., Pandian, A., ... Mahmood, W. A. K. (2004). Masalah Pengangguran di kalangan siswazah. Pulau Pinang: National Higher Education Research Institute, USM.

Topimin, S. (2006). Fostering entrepreneurship: a challenge for an education institution. Proceedings of the $2^{\text {nd }}$ National Entrepreneurship Conference held on 9-10 December 2006 at Vistana Hotel Pulau Pinang.

Wang, C. K., \& Wong, P. K. (2004). Entrepreneurial interest of university students in Singapore. Technovation, 24(2), 163-172. http://dx.doi.org/10.1016/S0166-4972(02)00016-0 